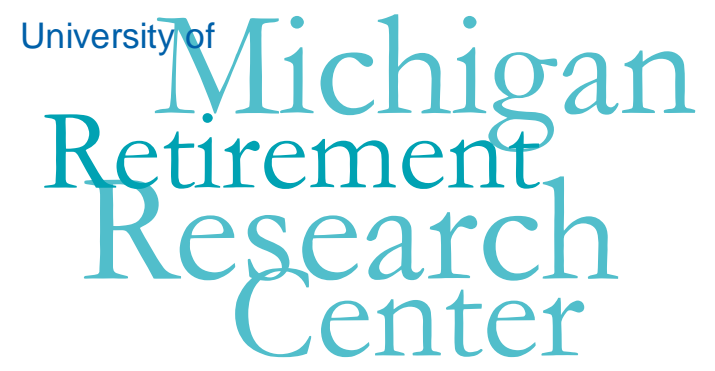

Working Paper

WP 2010-230

\title{
Cognitive Ability and Retiree Health Care Expenditure
}

\author{
Hanming Fang, Lauren Nicholas and Daniel Silverman
}

\begin{tabular}{|l|l|}
\hline $\mathrm{M}$ & $\mathrm{R}$ \\
\hline $\mathrm{R}$ & $\mathrm{C}$ \\
\hline
\end{tabular}

Project \#: UM10-20 


\title{
Cognitive Ability and Retiree Health Care Expenditure
}

\author{
Hanming Fang \\ University of Pennsylvania \\ Lauren Nicholas \\ University of Michigan \\ Daniel Silverman \\ University of Michigan \\ September 2010
Michigan Retirement Research Center
University of Michigan
P.O. Box 1248
Ann Arbor, MI 48104
http://www.mrrc.isr.umich.edu/
(734) 615-0422

\section{Acknowledgements}

This work was supported by a grant from the Social Security Administration through the Michigan Retirement Research Center (Grant \# 10-M-98362-5-01). The findings and conclusions expressed are solely those of the author and do not represent the views of the Social Security Administration, any agency of the Federal government, or the Michigan Retirement Research Center.

Regents of the University of Michigan

Julia Donovan Darrow, Ann Arbor; Laurence B. Deitch, Bingham Farms; Denise Ilitch, Bingham Farms; Olivia P. Maynard, Goodrich; Andrea Fischer Newman, Ann Arbor; Andrew C. Richner, Grosse Pointe Park; S. Martin Taylor, Gross Pointe Farms; Katherine E. White, Ann Arbor; Mary Sue Coleman, ex officio 


\title{
Cognitive Ability and Retiree Health Care Expenditure
}

\begin{abstract}
Prior research indicates that retirees with less cognitive ability are at greater financial risk because they have lower incomes yet higher medical expenditures. Linking HRS data to administrative records, we evaluate two hypotheses about why this group spends more on health: (1) they are in worse health; (2) they receive more expensive or less effective care for the same conditions. We find that the bulk, but not all, of the cross-sectional relationship can be attributed to the poorer health of those with lower cognitive functioning. Much of this relationship appears to be driven by coincident declines in cognitive ability and health. While, in this respect, the data have important limitations, we find no evidence of substantial differences in care, conditional on observable health.
\end{abstract}

\section{Authors’ Acknowledgements}

The results described here represent initial findings. Comments are welcome. We would like to thank Kathleen McGarry for helpful discussions. The research reported herein was pursuant to a grant from the U.S. Social Security Administration (SSA) funded as part of the Retirement Research Consortium (RRC). The findings and conclusions expressed are solely those of the authors and do not represent the views of SSA, any agency of the Federal Government or the MRRC. 


\section{Introduction}

The rapidly increasing costs of medical care are straining retiree incomes, along with the public and private insurance programs that serve them. Spending on the federal government's largest health insurance program, Medicare, represented 3.2 percent of GDP in 2008 and is projected to reach 5 percent of GDP by 2025 (Medicare Trustees, 2009). While enormous, this federal expenditure amounts to less than half of the total spent on health care for the elderly (Medicare Trustees, 2008; Kaiser Family Foundation, 2005). Medicare premium increases now outpace Social Security cost-of-living adjustments and represent a growing share of retiree budgets. It thus seems likely that retirees will increasingly need to accumulate private resources and turn to private markets in order to secure both their health and their consumption. It is therefore important to understand better the difficulties that retirees face in their efforts to accumulate such resources and navigate such markets.

There are many obstacles that retirees may face as they work to accumulate sufficient resources and make good choices in markets for health care and health insurance. These obstacles include uncertain income and health, incomplete insurance and asset markets, imperfect information about choices and their consequences, and deficiencies in the skills necessary to make good choices about saving and health in a complex environment. In this paper, we consider one such obstacle: a deficiency of cognitive abilities. Evidence from a variety of sources suggests that older people, and especially those with lower cognitive abilities, have difficulty navigating markets for health care and insurance. In addition, prior research (Fang et al., 2008) indicates that this population is spending more on health care than their more able peers; and that heterogeneity in cognitive abilities, at least as much as standard sources of economic variation, explains important differences in health insurance and expenditure 
behavior. In this paper, we use panel data from the Health and Retirement Study (HRS) linked to Medicare administrative claims files to investigate whether and how cognitive abilities relate to the level and qualities of medical expenditure among U.S. retirees.

In a first step, we use the HRS-Medicare linked data to describe the basic, contemporaneous correlation between cognitive function and medical expenditure; a correlation that previous research has shown to be negative in different data sets. Our estimates indicate that indeed, consistent with previous findings, older people with lower cognitive abilities spend substantially more on health than their better able peers. Having established that this basic relationship holds in these data, we then move on to consider alternative sets of hypotheses for why retirees with less cognitive ability spend more on health care.

The cross-sectional correlation between cognitive ability and health expenditure may be determined by a number of different mechanisms. One broad set of these mechanisms would attribute the relationship to the differences in contemporaneous health between those with higher and lower cognitive abilities. Those with lower cognitive abilities may be in worse health and thus require more (and more expensive) care. An alternative, not mutually exclusive, set of mechanisms would attribute the contemporaneous relationship between cognitive function and health expenditure to the nature or quality of the care received by people with different cognitive abilities, but similar underlying health.

To assess the empirical relevance of these alternative sets of mechanisms, we consider the extent to which contemporaneous measures of observable health that are correlated with cognitive function can explain the relationship estimated in the crosssection. Conditioning on a long list of observable health measures, we find that much, but not all, of the relationship between cognitive function and health expenditure can be explained by observable components of health. The remaining, conditional correlation between cognitive function and medical expenditure, is modest and allows 
several interpretations.

One interpretation of the remaining, conditional correlation between cognitive function and medical expenditure is that it reflects unobserved health associated with cognitive decline. To evaluate this hypothesis, we examine the importance of end-of-life expenditure and estimate fixed effect specifications identified off of withinperson changes in cognitive functioning. Our findings indicate that much of the cross-sectional correlation between cognitive function and health expenditure is due to decline, We interpret this as consistent with the view that the conditional (on observed health) correlation between cognitive function and medical expenditure is attributable to unobserved health.

An alternative set of explanations for the conditional (on observed health) correlation between cognitive function and medical expenditure is that the qualities of care differ for those with lower levels of cognitive functioning. Of particular interest is the possibility that less-able retirees are spending more because they tend to receive different, more costly or less effective, kinds of care, despite the same underlying health. To examine the plausibility of these explanations, we use the highly detailed Medicare claims data to investigate the qualities of the care received by respondents with different levels of cognitive function. Specifically, we estimate the relative frequency of three different types of hospitalizations, each indicating a potentially different set of mechanisms driving the cross-sectional relationship between cognitive ability and medical expenditure. The rarity of some of these hospitalizations may make it difficult to discern differences in the relative frequency of these events. Our estimates indicate, however, that (1) observable aspects of health are doing a relatively good job of controlling for unobserved aspects of health that are correlated with cognitive functioning; (2) differences in health investment behaviors and health care access are likely important contributors to the cross-sectional relationship between cognitive functioning and health care expenditure; (3) differences in health care received, despite very similar underlying health, do not much contribute to the cross-sectional 
relationship between cognitive function and health care expenditure.

We view this paper as the beginning of an inquiry into the mechanisms behind the cross-sectional correlation between cognitive abilities and medical expenditure. In future work, we anticipate gaining further confidence in the estimated relationships described here and investigating the role of different kinds of knowledge and cognitive ability in determining medical care choices.

The rest of the paper is structured as follows. In section 2, we discuss the related literature; in section 3, we describe the data sets used in our analysis; in section 4, we document the raw negative correlations between cognition measures and the total health expenditure, as well as hospitalization expenditures, and show that these negative correlations are largely explained away by controlling for differences in observed health variables; in Section 5 we examine whether the cross-sectional negative correlations between cognition and total health expenditures/hospitalization expenditures are a result of cognition declines; in Section 6 we inquire whether the negative correlation results from differences in the quality and effectiveness of health care received by patients with different cognitive abilities. We conclude and discuss the implications of our findings in Section 7.

\section{Related Literature}

An important motivation for our paper is the surprising negative relationship between health expenditure and supplemental Medigap insurance coverage among retirees, documented in Fang, Keane and Silverman (2008). In that paper, the authors find that an important source for the documented advantageous selection - namely, those who purchase Medigap insurance tend to spend less, instead of more, on health care - is cognition. Specifically, they found that in HRS data retirees with higher cognition ability are more likely than retirees with lower cognition to purchase the supplemental Medigap insurance, and as a group, those with higher cognition tend 
to spend less than those with lower cognition, even though, conditional on cognition there is the traditional adverse selection, i.e., those who purchase Medigap do tend to spend more on health. In this paper, we investigate why the group with lower cognition has higher health care expenditures and is thus at risk for lower consumption in retirement. In doing so, we would contribute to a burgeoning literature on the consequences of financial literacy and cognitive ability on wealth and health in retirement. Our paper is of course related to the literature, such as Cafferata (1984), Davidson et al. (1992), and Harris and Keane (1999), which provide evidence from a variety of sources suggests that older people, and especially those with less numeracy and cognitive ability, have difficulty navigating markets for health care and insurance.

Our paper is also related to a large growing literature on the quality of decision making. For example, Ameriks, Caplin and Leahy (2003) found strong evidence of the importance of planning in predicting wealth; Agarwal, Driscoll, Gabaix, and Laibson (2009) found a strong u-shaped correlation between financial "mistakes" and age. There is also growing evidence that reducing complexity in the choice options affects choice (see Hastings and Weinstein, 2008, for school choice, Kling et al, 2008, for medigap Part D plan choice and Bettinger et al, 2009, for loan applications, and Beshears, Choi, Laibson and Madrian, 2010, for retirement savings plan participation). The literature on the role of education in affecting decision making also suggests the importance of cognition. For example, Bernheim, Garrett and Maki (2001), Duflo and Saez (2003), and Bayer, Bernheim and Scholz (2009) showed that education plays an important role in determining savings decisions, above and beyond its effect on lifetime earnings. Cole and Shastry (2009) provide evidence for the importance of education, cognitive ability and financial literacy on financial market participation. 


\section{Data}

Our analysis relies on two linked data sets, the HRS and Medicare administrative claims data summarized, for each matched HRS respondent, in the Beneficiary Annual Summary File (BASF). Here we provide a brief description of these data.

\subsection{Health and Retirement Study}

The HRS began in 1992 as a panel survey of a nationally representative sample of people born between 1931 and 1941, and their spouses. This original cohort has been re-interviewed every other year since. In 1998, the objective of the HRS was expanded to include learning about the entire U.S. population over age 50. To achieve this goal, the original HRS survey was merged with an existing and related survey of individuals born in 1923 or before, the Asset and Health Dynamics among the Oldest Old. In addition, two more samples were added: the "Children of the Depression" cohort born between 1924 and 1930, and the "War Baby" cohort born between 1942 and 1947. Our interest in those over age 65 leads us to limit our analysis to data collected in the HRS waves from 1998-2008, the latest years for which a final version of the integrated data is available. Whenever possible we include data from all HRS cohorts.

\subsubsection{Cognitive Performance Measures}

The HRS collects a rich set of information about respondents' health, wealth, education, family structure, and the like. Of particular interest for our analysis are the several measures of cognitive performance gathered by the HRS. ${ }^{1}$ In this paper, we use measures of a respondent's performance on three different tests or sets of questions: word recall, number subtractions, and a Telephone Interview for Cognitive Status (TICS).

\footnotetext{
${ }^{1}$ See McCardle et al. (2007) for a recent summary.
} 
The word recall tests ask respondents to repeat, both immediately and then again five minutes later, a list of 10 words that the interviewer read to them, once, aloud. The subtraction tests include both the simple task of counting backward from 20 and the more difficult task of counting backward from 100 by 7s. Last, the TICS mental status measure asks respondents to give the last names of the President and Vice President of the U.S., to provide the current date and day of week, and to name two objects based on their brief description. ${ }^{2}$

While social scientists from a variety of disciplines have studied the qualities of these measures in great detail, ${ }^{3}$ the economic interpretation of both the measures and their correlations with economic outcomes remains underdeveloped. We therefore do not take a firm stand on the economic modeling and interpretation of these cognitive performance measures. Instead, we attempt to describe relationships between cognitive performance and health care expenditure and utilization, recognizing that these measures may proxy for an individual's ability to think through the costs and benefits of various economic decisions. This interpretation finds some support in the substantial body of literature showing that many of the elderly have difficulty understanding the basic Medicare entitlement, and/or the features of supplemental insurance. ${ }^{4}$

Factor Analysis The various measures of cognitive functioning collected by the HRS may capture several different, but not entirely distinct, aspects of ability relevant to health and health care choice. To ease interpretation and increase the statistical precision of our estimates, we use factor analysis and reduce the dimension of the cognitive function measures down to two factors. The first factor loads almost entirely on the two word recall tests. The second factor loads primarily on the TICS score and backward counting from 20. The factor loadings (with orthogonal rotation) are

\footnotetext{
${ }^{2}$ The first of these questions asks: What do people usually use to cut paper? The second naming question asks: What is the prickly green plant found in the desert?

${ }^{3}$ See, e.g., Herzog and Wallace (1997), Herzog and Rogers (1999).

${ }^{4}$ See, e.g., Harris and Keane (1999) for empirical evidence, Keane (2004) for a survey of the literature.
} 


\begin{tabular}{lccc}
\hline \hline \multicolumn{3}{c}{ Factor 1} & Factor 2 \\
\hline & std. dev. $=0.87$ & std. dev. 0.79 & \\
\hline & w/in-person std. dev $=0.48$ & w/in-person std. dev $=0.47$ & \\
\hline & btw-person std. dev $=0.78$ & btw-person std. dev $=0.73$ & Uniqueness \\
\hline Variable & & & 0.310 \\
Word recall, immediate & 0.809 & 0.190 & 0.319 \\
Word recall, delayed & 0.808 & 0.167 & 0.746 \\
Backward counting from 20 & 0.098 & 0.652 & 0.565 \\
TICS & 0.334 & 0.702 & 0.395 \\
Subtraction from 100 by 7s & 0.338 & 0.375 & 0.375 \\
\hline
\end{tabular}

Table 1: Two Cognition Factors.

presented in Table 1. The uniqueness measure indicates that the two factors explain all but the subtraction by 7 s reasonably well.

This study links HRS survey data to Medicare administrative claims data for respondents who have previously consented to its release. Beginning in 1993, respondents who were at least 65 years old were asked to provide their Medicare number to facilitate the linkage for research purposes. Consenting respondents provide access to current, prior and future Medicare claims data, creating longitudinal measures of health care utilization and spending. We use Medicare claims data from 1998-2007 for this study. We merge annual Medicare data from the year a respondent completed an HRS interview with survey responses. We exclude observations from Medicare managed care enrollees because plan reports of members' utilization are incomplete and unreliable during the study period (Asper, 2009). This leaves us with an analysis sample of 11,150 respondents and 34,535 person-wave observations. 


\subsection{Medicare Expenditure Data}

We use the Medicare Beneficiary Annual Summary File (BASF) for measures of Medicare spending on a beneficiary's care. ${ }^{5}$ Several spending measures are included, including total Medicare spending, inpatient, outpatient, skilled nursing, hospice and home health expenditures. All dollar amounts are adjusted to 2007 totals using the medical care component of the Consumer Price Index.

\subsection{Hospitalizations}

Inpatient hospital care accounts for a significant component of Medicare spending. We use MedPAR inpatient hospitalization records to construct indicators of whether a beneficiary experiences an emergent or elective hospitalization in the interview year. International Classification of Disease (ICD-9) diagnostic and procedure codes are used to identify three different types of hospitalizations amongst Medicare beneficiaries.

1. Marker Admissions are hospitalizations for three different conditions: appendicitis, hip fracture and gastrointestinal obstruction. These conditions are such that ambulatory care just before admission is unlikely to affect the need to be hospitalized (Billings et al. 1993). In this way, marker conditions are relatively good indicators of (unobserved) underlying health as opposed to health choices or access to care.

2. Ambulatory Care Sensitive (ACS) Admissions are potentially avoidable hospitalizations for conditions that can be managed or prevented through effective primary care, such as complications of diabetes or high blood pressure. ACS admissions often signify lack of access to primary care, receipt of low-quality services, or inability to manage chronic conditions (Billings et al., 1996). Acute

\footnotetext{
${ }^{5}$ See http://hrsonline.isr.umich.edu/sitedocs/rda/cmsdocs/basf_fdd/Public_RDDC_Data_BASF_FrontF for an enhanced BASF data dictionary.
} 
admissions are potentially preventable through timely outpatient intervention or vaccination, while chronic conditions may require ongoing monitoring and patient compliance.

3. Referral-Sensitive Admissions include elective surgical procedures, such as hip or knee replacement and coronary artery bypass graft. These are high-cost procedures that can improve patient well-being and generally require a referring physician, indicating that outpatient service use prior to the admission (Billings, 2003; Billings et al., 1993). From an efficiency standpoint, it is unclear whether higher or lower rates of these admissions are desirable. These procedures should be performed in accordance with patient preferences (Wennberg, 2007).

\subsection{Summary Statistics}

Table 2 provides summary statistics of the key dependent variables we use in our analysis. The first row summarizes the individual annual medical expenditure (in 2007 dollars) that is eligible for at least partial reimbursement from Medicare. On average, this amounts to $\$ 5,513$ a year. As has been often noted, there is enormous variability in this expenditure; the standard deviation of the distribution of this measure is more than twice the mean. Subsequent rows of Table 2 restrict attention to that portion of expenditure that is actually reimbursed by Medicare, and breaks this amount down by category of expenditure. These statistics show that inpatient care is the largest category, on average, followed by "carrier" and out patient care. ${ }^{6}$ Expenditure on skilled nursing and home health care are also substantial, on average.

The bottom half of Table 2 summarizes some aspects of the disaggregated claims data. In particular this part of Table 2 describes the prevalence of hospital admissions for marker, ACS and referral sensitive conditions. Importantly, the table shows that our primary marker condition, hip fracture, is quite rare in the data. Similarly, the

\footnotetext{
${ }^{6}$ These will tend to be "Part B" expenditure for doctor visits, outpatient care, lab work, etc.
} 
referral sensitive admissions are also rare. ACS admissions, both chronic and acute, are considerably more frequent. The rarity of marker and referral sensitive admissions will limit our ability to draw inference from their relative frequency among those with lower levels of cognitive functioning.

[Table 2 About Here]

\section{Cognitive Function, Health Expenditure and Health}

\subsection{Cognitive Function and Health Expenditure - Raw Cor- relations}

As a first step, we use the HRS-Medicare linked data to assess the basic relationship between cognitive function and medical expenditure- a relationship that previous research has shown to be negative in different data sets. The goal of this first step is simply to quantify, in these unusually high quality HRS-Medicare linked data, the contemporaneous relationship between cognitive function and a central component of medical expenditure among the elderly. Specifically, we estimate the following "pooled" regression equation by OLS:

$$
y_{i t}=\alpha+\beta_{1} f_{1 i t}+\beta_{2} f_{2 i t}+\mathbf{X}_{i t}^{\prime} \boldsymbol{\beta}_{3}+\iota_{t}+\varepsilon_{i t}
$$

where $y_{i t}$ denotes the level of Medicare-eligible health expenditure by individual $i$ in year $t, f_{j i t}$ is individual $i$ 's cognitive ability factor $j$ in year $t, \mathbf{X}_{i t}$ is a vector of limited and predetermined demographic controls at year $t,{ }^{7} \iota_{t}$ is a year- $t$ specific intercept and $\varepsilon_{i t}$ an error term. In calculating the standard errors we allow for arbitrary correlation of the error terms within individuals. ${ }^{8}$

\footnotetext{
${ }^{7}$ These controls include indicators for gender and race, and a cubic in age.

${ }^{8}$ Note that in equation 1 , we do not include controls for education or financial resources. The effects of these variables will be assessed later.
} 
Table 3 reports the basic correlation between the cognition factors and various categories of medical expenditures from the Medicare BASF data, without controlling for observable health measures. The point estimates indicate that an increase by one standard deviation $(0.87)$ in cognition factor $f_{1}$ reduces the total annual medical expenditure by 816 dollars, and this reduction is statistically significant at $1 \%$ level. Recall that the average total expenditure is approximately $\$ 5,500$. A standard deviation (0.79) increase in cognition factor $f_{2}$ reduces total medical expenditure by 447 dollars, again a reduction statistically significant at $1 \%$ level. The same negative relationship is also found between the two cognition factors and all subcategories of Medicare reimbursed medical expenditure. With the exception of one coefficient estimate (which is statistically significant at 5\% level), all other estimated reductions are statistically significantly at $1 \%$ level.

\section{[Table 3 About Here]}

\subsection{Can Observable Health Explain the Raw Correlation?}

The contemporaneous relationship between cognitive ability and health expenditure estimated in equation 1 may be determined by a number of different mechanisms. One broad set of these mechanisms would attribute the relationship to the differences in contemporaneous health between those with higher and lower cognitive abilities. Those with lower cognitive abilities may be in worse health and thus require more (and more expensive) care. An alternative set of mechanisms would attribute the contemporaneous relationship between cognitive function and health expenditure to the nature or quality of the care received by people with different cognitive abilities, but similar underlying health.

To begin to assess the quantitative importance of these alternative sets of mechanisms, we first consider the extent to which contemporaneous measures of observable health that are correlated with cognitive function can explain the relationship esti- 
mated in equation 1. To that end, we estimate by OLS the following equation:

$$
y_{i t}=\alpha+\beta_{1} f_{1 i t}+\beta_{2} f_{2 i t}+\mathbf{X}_{i t}^{\prime} \boldsymbol{\beta}_{3}+\mathbf{H}_{i t}^{\prime} \boldsymbol{\beta}_{4}+\iota_{t}+v_{i t},
$$

where we have added to the set of regressors in equation 1 a vector, $\mathbf{H}_{i t}$, of observable (objective and subjective) health characteristics. ${ }^{9}$

Table 4 reports the estimated coefficients of specification 2, where we include, but do not report the coefficient estimates of, a large list of observed health measures, such as self-reported health (poor, fair, good, very good and excellent, as well as non-reporting dummies), a large list of indicators for difficulty in performing (instrumental) activities of daily living (e.g., difficulty in using toilet, difficulty in eating etc.), as well as a long list of variables indicating whether the individual had ever been diagnosed with certain health conditions (e.g., heart disease, cancer, had high blood pressure, etc.). The estimated coefficients in Table 4 indicate that the magnitude of the relationship between cognitive function and health expenditure is substantially reduced once the observed health conditions are controlled for. For example, the relationship between total medical expenditure and cognition factors $f_{1}$ and $f_{2}$ are still negative in this regression, but the coefficient estimates are no longer statistically significant. In some subcategories of expenditure, the conditional correlation remains statistically significant and negative. In addition, typically the cognition measures are jointly significant, even when the observed health measures are controlled for.

\section{[Table 4 About Here]}

This contemporaneous relationship between cognition measures and various measures of health expenditure still hold, and indeed tend to increase in absolute magnitude and statistical significance if we also include controls for education and contemporaneous financial resources. We will return to the interpretation of these supplemental estimates of later in the paper.

\footnotetext{
${ }^{9}$ See the appendix for a detailed description of these measures.
} 
Table 5 presents the results of specifications that allow for non-linear effects of the cognitive factors on various categories of medical expenditure. Specifically, we allow for the lowest quartile of the cognition measures to have different intercepts and slopes with respect to medical expenditure. Panel A reports the coefficient estimates on the cognition measures $f_{1}$ and $f_{2}$ when observable health is not controlled for and Panel $\mathrm{B}$ reports the corresponding coefficient estimates when observable health is controlled for. The point estimates are somewhat imprecise. They echo, however, the results of the linear specifications. The point estimates indicate a sizeable negative correlation between cognitive functioning and medical expenditure that is importantly, but not entirely, explained by differences in observable health.

[Table 5 About Here]

\section{Mechanisms: Health and Cognitive Decline}

There are several potential mechanisms that could lead cognitive function to be correlated with health and, thus, health expenditure. One set of mechanisms derive from the changes in cognitive function associated with declining general health. This set of mechanisms is the direct consequence of biology or medicine, rather than the choices of individuals; they would attribute the correlations implied by the estimates of equations 1 and 2 to the contemporaneous loss of cognitive function that comes as people get ill and seek (costly) health care (see, e.g., Rohwedder and Willis, 2010). In this view, the fact that cognitive function still predicts health expenditure in the estimates of 2 is due to the conditional correlation between cognitive function and unobserved (by the econometrician) elements of health; it is due, that is, to a correlation between cognitive function and unobserved health, conditional on observed health. ${ }^{10}$

\footnotetext{
${ }^{10}$ Unobserved health that is conditionally correlated (either positively or negatively) with observable health but not cognitive function would bias estimates of the coefficients on the observable
} 
An alternative, and related set of mechanisms behind the correlations estimated in equations 1 and 2 derives from persistent heterogeneity in cognitive abilities. In this view, people vary in a persistent component of cognitive function; and a (long) history of health investment and care decisions with lower cognitive abilities leads people to reach old age with poorer general health. This poorer general health then induces greater demand for health expenditure. In this view, the fact that cognitive function still predicts health expenditure in the estimates of 2 would again be attributed to the conditional correlation between cognitive function and unobserved (by the econometrician) elements of health. In this section, we take several approaches to empirically evaluate the relative importance of cognitive decline versus persistent cognitive heterogeneity in determining the cross-sectional relationship between cognitive function and health expenditure.

\subsection{Declines of Observable Health and Cognitive Function}

To begin to assess the roles played by cognitive decline versus persistent cognitive heterogeneity, we first describe some basic features of the time path of observable health and cognitive function. If the cross-sectional relationship between cognitive ability and health expenditure were driven by the coincident decline of both mental function and general health, then we should be able to detect that coincident decline in observable health.

A simple analysis of the variance in cognitive function indicates substantial variation in these measures both across individuals and within a single individual over time. Returning to Table 1, we see that the between-individual standard deviation is 0.78 for the first cognitive factor and 0.73 for the second. The comparable statistics for within-individual variation are 0.48 and 0.47 . Overall, the standard deviation of these measures are 0.87 and 0.79 , respectively. ${ }^{11}$

health variables, but not the coefficients on cognitive functions.

${ }^{11}$ By construction, each factor is mean zero. 
Examining the relationship of wave-to-wave, within-person changes in health and cognitive function gives a sense of how cognitive functioning moves with observable health. We estimate models of fixed effects in cognitive function and observable health, and see the expected positive relationship. Table 6 shows that declines in self-reported health and increases in the number of (I)ADLS with which the respondent has difficulty have strong, negative associations with cognitive functioning. As these estimates are identified by within-person changes in both cognitive function and observable health, they point to important positive co-movements of health and cognitive functioning and are consistent with substantial effects of cognitive decline.

\section{[Table 6 About Here]}

\subsection{End-of-Life Expenditure}

To further assess the relative importance of cognitive decay versus persistent heterogeneity in cognitive function, we examine the special case of end-of-life expenditure. Average end-of-life medical expenditure is large; it now represents approximately a third of total Medicare expenditure. To the extent that cognitive decline associated with poor health drives the cross-sectional relationship estimated in equations 1 and 2 , conditioning on being in the end of life should reduce the importance of cognitive function in predicting medical expenditure. To evaluate this proposition, we restrict attention to the Medicare-matched HRS respondents who died during the study and estimate the relationship between cognitive functioning and expenditure, conditional on whether the respondent was in the end of life.

Table 7 reports the estimation results controlling for the "end of life," indicating the observation year was the last of the respondent's life. Panel A, which does not include controls of observable health, shows that even if one controls for the end of life dummy, which is estimated to be very large (around $\$ 9500$ for total medical expenditure), the coefficients on the cognition measures remain negative and statistically significant. In fact, the magnitude of these estimates are only slightly 
smaller than their corresponding estimates in Table 3. The estimates in Panel A thus indicate that, the basic cross-sectional relationship is not driven entirely by the cognitive decline associated with death. However, Panel B shows again that this negative correlation between cognitive functioning and health expenditures is importantly, if not completely explained by measures of health. The point estimates lack statistical precision but, as in Table 3, we find evidence that the very bottom of the cognitive functioning distribution has substantially higher medical expenditure, even conditional on observable health.

[Table 7 About Here]

\subsection{Fixed Effects}

In a final approach to evaluating the relative contribution of cognitive decline to the cross-sectional relationship, we return to the full sample and estimate "fixed effects" equations of the following form:

$$
\begin{aligned}
& y_{i t}=\alpha+\beta_{1} f_{1 i t}+\beta_{2} f_{2 i t}+\mathbf{X}_{i t}^{\prime} \boldsymbol{\beta}_{3}+\iota_{t}+\omega_{i}+\tilde{\varepsilon}_{i t} \\
& y_{i t}=\alpha+\beta_{1} f_{1 i t}+\beta_{2} f_{2 i t}+\mathbf{X}_{i t}^{\prime} \boldsymbol{\beta}_{3}+\mathbf{H}_{i t}^{\prime} \boldsymbol{\beta}_{4}+\iota_{t}+\omega_{i}+\check{\varepsilon}_{i t} .
\end{aligned}
$$

These specifications estimate the relationship between with-in person changes in cognitive functioning and observable health and medical expenditure.

Table 8 reports the results from the fixed effect regressions. Panel A does not control for observable health, but allows for the lowest quartile of the cognition measures to have different effects on the medical expenditures. It shows that the negative relationships between measures of cognition and various health expenditure continue to hold in fixed effect regressions, if we do not control for observable health; more interestingly, these negative relationships continue to hold even when we control for observable health, at least for those whose cognition measures are not in the lowest quartile.

[Table 8 About Here] 


\subsection{Discussion and Interpretation}

As noted above, to the extent that the additional expenditure associated with low cognitive functioning is due to coincident declines of general health and cognitive ability, one interpretation of the residual correlation between cognitive functioning measures and expenditure is simply unmeasured health. Those with lower cognitive functioning are, in ways unobservable to the econometrician, in worse health and thus demand more and more expensive health care. An alternative, though not mutually exclusive, explanation for the residual correlation is that the qualities of care differ for those with lower cognitive functioning. Of particular interest is the possibility that less able retirees are spending more because they tend to receive different, more costly or less effective, kinds of care.

Similarly, there are alternative interpretations or explanations for the extent to which the higher health expenditures among lower cognitive ability people is explained by persistent heterogeneity in cognition. One explanation is that prior health investments have generated worse unobserved health. Again, another not mutually exclusive explanation is that, conditional on health, resources and access, the quality of care provided to those with persistently lower cognitive abilities is more costly or less effective.

In the next section we examine disaggregated claims data to understand better the qualities of retiree care, by level of cognitive functioning. In doing so, we look for evidence that those with lower cognitive abilities use health care services indicative of either different levels of unobserved health (demand) or different qualities of care (supply). 


\section{Mechanisms: Cognitive Function and Qualities of Care}

In this section we make use of the highly detailed Medicare claims data to examine the qualities of the care received by respondents with different levels of cognitive function. We use MedPAR inpatient hospitalization records to construct indicators of whether a beneficiary experiences a hospitalization of various types in the interview year. International Classification of Disease (ICD-9) diagnostic and procedure codes are used to identify the various types of hospitalizations among Medicare beneficiaries.

\subsection{Marker Conditions}

First, we examine the relative frequency of hospital admissions for a "marker" condition, by level of cognitive functioning. Marker conditions, which include hip fracture, appendicitis, and gastrointestinal obstruction, are diagnoses for which ambulatory care just before admission is unlikely to affect the need to be hospitalized (Billings et al. 1993). In this way, marker conditions are relatively good indicators of underlying health as opposed to health choices or access to care.

We estimate models of the following form:

$$
I_{i t}=\eta+\gamma_{1} f_{1 i t}+\gamma_{2} f_{2 i t}+\mathbf{X}_{i t}^{\prime} \gamma_{3}+\mathbf{H}_{i t}^{\prime} \gamma_{4}+\iota_{t}+\breve{\varepsilon}_{i t}
$$

where $I_{i t}$ is an indicator equal to one if respondent $i$ had a marker admission in year $t$ and zero otherwise. If the estimates of equation 5 indicate an important conditional correlation between cognitive functioning and hospitalization for marker conditions $\left(\hat{\gamma}_{1}, \hat{\gamma}_{2}\right.$ non-zero) we will interpret that as evidence of an important conditional correlation between cognitive function and unobservable health. If, instead, the $\hat{\gamma}_{1}$ and $\hat{\gamma}_{2}$ are precisely estimated zeros, we will interpret that as evidence that our measures of observable health are doing well at controlling the unobserved aspects of health correlated with cognitive functioning. Column 1 of Table 9 presents results for the 
marker condition that is most common in our data, a hip fracture. Comparing Panels $\mathrm{A}$ and $\mathrm{B}$ indicates that, by adding our controls for observable health we reduce the magnitude of the estimated (negative) relationship between cognitive function and the marker condition. The point estimate becomes a fairly precisely estimated zero. We interpret this as evidence, somewhat contrary to some of the findings presented above, that observable health is doing a good job of controlling for unobservable aspects of health that are, conditionally, correlated with cognitive functioning.

\subsection{Ambulatory Care Sensitive Conditions}

Investigating the qualities of care further, we turn to examine the relative frequency of "Ambulatory Care Sensitive" (ACS) admissions. ACS admissions are hospitalizations for conditions that can be managed or prevented through effective primary care, such as complications of diabetes or high blood pressure. ACS admissions often signify lack of access to primary care, receipt of low-quality services, or inability to manage chronic conditions (Billings et al., 1996). Acute admissions are potentially preventable through timely outpatient intervention or vaccination, while chronic conditions may require ongoing monitoring and patient compliance. We examine both acute and chronic conditions by estimating a linear probability model for each class of conditions:

$$
I_{i t}=\phi+\phi_{1} f_{1 i t}+\phi_{2} f_{2 i t}+\mathbf{X}_{i t}^{\prime} \phi_{3}+\mathbf{H}_{i t}^{\prime} \phi_{4}+\iota_{t}+\breve{\varepsilon}_{i t} .
$$

Here $I_{i t}$ is an indicator equal to one if respondent $i$ had an ACS admission in year $t$ and zero otherwise.

The results are presented in columns 2 and 3 of Table 9 . Here we see that increases in cognitive functioning are associated with statistically significant decreases in both acute and chronic ACS admissions. Conditioning on observable health diminishes the magnitude of the relationship, but does not explain it entirely. We interpret this relationship between cognitive function and ACS admissions, conditional on health, as 
reflecting a conditional correlation between cognitive ability and unobservable health. Those unobserved health differences might reflect either differences in access to care or differences in adherence to care.

\section{[Table 9 About Here]}

\subsection{Referral-Sensitive Admissions}

By isolating the relative frequency of ACS admissions, we focused on preventable conditions. In this subsection we analyze certain "referral-sensitive" hospital admissions including joint replacement and elective heart surgery. These are hospital admissions for treatments that require an out-patient referral; and the treatments are aimed at conditions for which less invasive and aggressive options are available. Making use of the disaggregated utilization data, we estimate a linear probability model of the following form:

$$
R_{i t}=\mu+\rho_{1} f_{1 i t}+\rho_{2} f_{2 i t}+\mathbf{X}_{i t}^{\prime} \boldsymbol{\rho}_{3}+\mathbf{H}_{i t}^{\prime} \boldsymbol{\rho}_{4}+\iota_{t}+\stackrel{\circ}{\varepsilon}_{i t},
$$

where $R_{i t}$ is an indicator equal to one if respondent $i$ had an referral-senstive admission in year $t$ and zero otherwise.

The results are presented in columns 4 and 5 of Table 9 . Here we see an important limitation of the data. These referral sensitive admissions are so rare that any changes in relative frequencies may be hard to detect in finite samples. With this caveat in mind, we find no evidence of differences in the relative frequency of these types of admissions by level of cognitive functioning. The point estimates indicate very a small unconditional relationship that is largely eliminated when we condition on observable health. We interpret these findings to indicate that, in these domains, older people are not receiving more or less aggressive treatment depending on their level of cognitive functioning. This is not a judgment about the efficacy of the differing treatments; receiving a joint replacement despite the absence of a broken hip may be a proper and cost-effective treatment. 


\section{Conclusions}

Linking the rich panel survey data of the HRS to administrative data on Medicare claims, this paper investigated the relationship between cognitive abilities and medical expenditure among older Americans. Consistent with previous studies, we found that older people with lower cognitive abilities spend substantially more on health than their better able peers. Having confirmed this regularity in these unusually high quality data, we turned to start investigating the channels through which this correlation emerges.

The cross-sectional correlation between cognitive ability and health expenditure may emerge via several different channels. One broad set of such channels would attribute the relationship to the differences in contemporaneous health between those with higher and lower cognitive abilities. Alternatively, the contemporaneous relationship might be due to differences in the nature or quality of the care received by people with different cognitive abilities, but similar underlying health.

Conditioning on a long list of observable health measures, we find that much, but not all, of the relationship between cognitive function and health expenditure can be explained by observable components of health. The remaining, conditional correlation between cognitive function and medical expenditure, is modest and allows several interpretations. Much of our evidence on expenditure (as opposed to utilization) is consistent with the hypothesis that the conditional correlation between cognitive function and medical expenditure reflects unobserved health associated with cognitive decline. We see this in the importance of end-of-life expenditure and the substantial correlation between cognitive functioning and health expenditure, conditional on individual fixed effects.

Our examination of utilization suggests that differences in (un)observable health by level of cognitive functioning may, in part, be determined by differences in the management of health conditions or access to care. We see this in the relatively strong, negative correlation between ACS admissions and cogntive functioning, even 
conditional on observable health. Our investigation of variation in the "intensity" of care for patients with the same observable health is limited by the rarity of admissions for conditions where this distinction can be made with greater certainty. With that caveat in mind, conditional on observable health we find no evidence of differences in health care received by level of cognitive function.

We view this paper as a first step along a path toward a better understanding of the mechanisms behind the cross-sectional correlation between cognitive abilities and medical expenditure. In future work, we anticipate gaining further confidence in the estimated relationships described here and investigating the role of different kinds of knowledge and cognitive ability in determining medical care choices. 


\section{References}

[1] Agarwal, Sumit, John Driscoll, Xavier Gabaix, and David Laibson. 2009. The Age of Reason: Financial Decisions over the Life-Cycle and Implications for Regulation. Brookings Papers on Economic Activity. No. 2, 51-117.

[2] Ameriks, John, Andrew Caplin and John Leahy (2003). "Wealth Accumulation and the Propensity to Plan." Quarterly Journal of Economics, 118, 1007-1047.

[3] Asper, F. (2009). Medicare Managed Care Enrollees and the Medicare Utilization Files. Minneapolis: Research Data Assistance Center Publication TN009.

[4] Buccaneer. (2009). Chronic Conditions Warehouse User Manual Version 1.5

[5] Billings J.(2003). "Using administrative data to monitor access, identify disparities, and assess performance of the safety net," in Tools for Monitoring the Health Care Safety Net. Rockville, MD: Agency for Health care Research and Quality.

[6] Billings J., G. Anderson, and L.Newman (1996). "Recent findings on preventable hospitalizations," Health Affairs, 15, 3, 239-49.

[7] Billings J., L. Zeitel, J. Lukomnik (1993). "Impact of socioeconomic status on hospital use in New York City," Health Affairs, 12,1, 162-73.

[8] Cafferata, Gail L. 1984. "Knowledge of their Health Insurance Coverage by the Elderly." Medical Care 22 (September): 835-847.

[9] Davidson, Bruce, Shoshanna Sofaer and Paul Gertler. 1992. "Consumer Demand and Biased Selection in the Demand for Coverage Supplementing Medicare." Social Science and Medicine 34 (9): 1023-1034

[10] Fang, Hanming, Michael P. Keane and Dan Silverman (2008). "Sources of Advantageous Selection: Evidence from the Medigap Insurance Market." Journal of Political Economy, Vol. 116, No. 2, 303-350. 
[11] Harris, Katherine and Michael Keane. 1998. "A Model of Health Plan Choice: Inferring Preferences and Perceptions from a Combination of Revealed Preference and Attitudinal Data." J. Econometrics 89 (November): 131-157.

[12] Hastings, Justine and Jeffrey Weinstein (2008). "Information, School Choice, and Academic Achievement: Evidence from Two Experiments." Quarterly Journal of Economics, November 2008.

[13] Herzog, A. R., \& Rodgers, W. L. (1999). "Cognitive performance measures in survey research on older adults." In N. Schwarz, D. Park, B. Knauper, \& S. Sudman (Eds.), Aging, Cognition, and Self-reports, pp. 327-340. Philadelphia: Psychology Press.

[14] Herzog, A. R., \& Wallace, R. B. (1997). "Measures of cognitive functioning in the AHEAD study." Journals of Gerontology, Series B: Psychological Sciences and Social Sciences, 52:37-48.

[15] McCardle, John J., Fisher, Gwenith G. and Kadlec, Kelly M. (2007). "Latent Variable Analyses of Age Trends of Cognition in the Health and Retirement Study, 1992-2004." Psychology and Aging, 22(3):525-545.

[16] Susann Rohwedder and Robert J. Willis (2010). "Mental Retirement." Journal of Economic Perspectives, Vol. 24, No. 1, 119-138.

[17] Saha S., Ady O., and Bindman A. "Impact of the Oregon Medicaid Demonstration on Preventable Hospitalization Rates." Academy Health Conference 2003. Available from: URL: http://www.oregon.gov/DAS/OHPPR/OHREC/Docs/ Preventions/ImpHospRts11_03.pdf

[18] UCSF-Stanford Evidence-based Practice Center. Refinement of the HCUP quality indicators. Rockville, MD: Agency for Health care Research and Quality; (2001). 
[19] United States Administration on Aging. (2004). Statistics: Aging into the 21st century.

[20] Weineck, R.A. and J. Billings, eds. (2003). "Tools for monitoring the health care safety net." AHRQ Publication No. 03-0027, Rockville, MD: AHRQ.

[21] Wennberg, J. E., E. S. Fisher, et al. (2002). "Geography and the debate over Medicare reform." Health Affairs Web Exclusive: hlthaff.w2.96.

[22] Wennberg, J. E., A. M. O'Connor, E. D. Collins and J. N. Weinstein (2007). "Extending the P4P agenda Part 1: How Medicare can improve patient decision making and reduce unnecessary care," Health Affairs, 26, 6, 1564 - 1574. 
Table 2: Summary Statistics of Dependent Variables.

\begin{tabular}{lccccc}
\hline Variable & Obs & Mean & Std. Dev. & Min & Max \\
\hline Total Medicare-eligible expenditure & 41460 & 5513.6 & 12589.2 & -113.0 & 379224.3 \\
Medicare reimbursement -- inpatient & 41460 & 2662.1 & 9051.3 & -226.9 & 345797.8 \\
Medicare reimbursement -- hospice & 41460 & 90.3 & 1554.0 & 0.0 & 52949.0 \\
Medicare reimbursement -- home health & 41460 & 351.0 & 1913.1 & 0.0 & 61779.0 \\
Medicare reimbursement -- med. equip. & 41460 & 226.6 & 1021.8 & 0.0 & 59973.9 \\
Medicare reimbursement -- carrier & 41460 & 1733.9 & 3165.7 & 0.0 & 87649.8 \\
Medicare reimbursement -- out patient & 41460 & 707.0 & 2628.6 & -608.9 & 61783.1 \\
Medicare reimbursement -- skilled nursir & 41460 & 395.2 & 2538.1 & 0.0 & 55713.0 \\
\hline & & & & & \\
Marker Admission & & & & & \\
\hline Hip fracture & 41460 & 0.012 & 0.156 & 0 & 6 \\
Ambulatory Care Sensitive Admissions & & & & & \\
Any ACS admission & 41460 & 0.085 & 0.419 & 0 & 10 \\
Acute ACS admission & 41460 & 0.033 & 0.221 & 0 & 7 \\
Chronic ACS admission & 41460 & 0.051 & 0.325 & 0 & 8 \\
& & & & & \\
\hline Referral Sensitive Admissions & & & & & \\
\hline Joint replacement (joint not broken) & 41460 & 0.015 & 0.126 & 0 & 2 \\
Coronary artery bypass surgery & 41460 & 0.006 & 0.076 & 0 & 1 \\
\hline
\end{tabular}


Table 3: Cross-Sectional Correlation Between Cognition Factors and Various measures of Medical Expenditures

\begin{tabular}{|c|c|c|c|c|c|c|c|c|}
\hline & $\begin{array}{c}\text { Total Medicare } \\
\text { Eligible } \\
\text { Expenditure } \\
\text { b/se }\end{array}$ & $\begin{array}{c}\text { Inpatient } \\
\text { Expenditure } \\
\text { b/se }\end{array}$ & $\begin{array}{c}\text { Hospice Care } \\
\text { Expenditure } \\
\text { b/se }\end{array}$ & $\begin{array}{l}\text { Home Health } \\
\text { Care } \\
\text { Expenditure } \\
\text { b/se }\end{array}$ & $\begin{array}{c}\text { Medical } \\
\text { Equipment } \\
\text { Expenditure } \\
\text { b/se }\end{array}$ & $\begin{array}{c}\text { "Carrier" } \\
\text { Medical } \\
\text { Expenditure } \\
\text { b/se }\end{array}$ & $\begin{array}{c}\text { Oupatient } \\
\text { Medical } \\
\text { Expenditure } \\
\text { b/se } \\
\end{array}$ & $\begin{array}{c}\text { Skilled Nursing } \\
\text { Facility } \\
\text { Expenditure } \\
\text { b/se }\end{array}$ \\
\hline f1 & $\begin{array}{c}-938.430 \star \star \star \star \\
(99.62)\end{array}$ & $\begin{array}{c}-525.689 * \star \star \\
(76.49)\end{array}$ & $\begin{array}{c}-24.998^{\star \star} \\
(8.60)\end{array}$ & $\begin{array}{c}-123.287^{\star \star \star} \\
(13.75)\end{array}$ & $\begin{array}{c}-47.441^{\star \star \star} \\
(6.96)\end{array}$ & $\begin{array}{c}-103.115^{\star \star \star} \\
(24.68)\end{array}$ & $\begin{array}{c}-97.793^{\star \star \star} \\
(17.60)\end{array}$ & $\begin{array}{c}-133.334^{\star \star \star} \\
(13.77)\end{array}$ \\
\hline 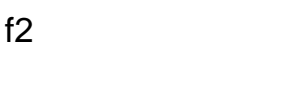 & $\begin{array}{c}-566.046^{\star \star \star} \\
(103.43)\end{array}$ & $\begin{array}{c}-281.299 * * \star \\
(74.08)\end{array}$ & $\begin{array}{c}-46.308^{\star \star \star} \\
(13.67)\end{array}$ & $\begin{array}{c}-83.425^{\star \star \star} \\
(18.82)\end{array}$ & $\begin{array}{c}-38.232^{\star \star \star} \\
(10.79)\end{array}$ & $\begin{array}{c}-12.074 \\
(22.61)\end{array}$ & $\begin{array}{c}-45.776^{\star} \\
(18.42)\end{array}$ & $\begin{array}{c}-131.065^{\star \star \star} \\
(24.45)\end{array}$ \\
\hline black & $\begin{array}{l}-229.123 \\
(235.46)\end{array}$ & $\begin{array}{l}-206.911 \\
(153.48)\end{array}$ & $\begin{array}{c}-23.563 \\
(19.49)\end{array}$ & $\begin{array}{l}59.984 \\
(38.87)\end{array}$ & $\begin{array}{l}67.589 * \\
(26.55)\end{array}$ & $\begin{array}{c}-187.896 * * \\
(62.74)\end{array}$ & $\begin{array}{c}212.241^{\star \star} \\
(69.77)\end{array}$ & $\begin{array}{c}-182.300^{\star \star \star} \\
(36.89)\end{array}$ \\
\hline hispanic & $\begin{array}{c}1215.630 * * \\
(458.08)\end{array}$ & $\begin{array}{l}411.392 \\
(265.19)\end{array}$ & $\begin{array}{c}-72.809 * \star \star \\
(13.12)\end{array}$ & $\begin{array}{c}484.850 * * \star \\
(117.90)\end{array}$ & $\begin{array}{c}174.045^{\star \star} \\
(57.32)\end{array}$ & $\begin{array}{l}299.516^{*} \\
(129.13)\end{array}$ & $\begin{array}{l}223.162 \\
(136.67)\end{array}$ & $\begin{array}{c}-186.148^{\star \star *} \\
(56.11)\end{array}$ \\
\hline race other & $\begin{array}{l}-444.68 \\
(608.63)\end{array}$ & $\begin{array}{l}-216.802 \\
(331.27)\end{array}$ & $\begin{array}{c}1.794 \\
(27.30)\end{array}$ & $\begin{array}{l}-32.831 \\
(174.51)\end{array}$ & $\begin{array}{c}-87.068 \\
(46.77)\end{array}$ & $\begin{array}{l}-150.819 \\
(173.16)\end{array}$ & $\begin{array}{c}48.624 \\
(138.21)\end{array}$ & $\begin{array}{c}-59.839 \\
(82.69)\end{array}$ \\
\hline race non-response & $\begin{array}{l}2595.076 \\
(2615.42)\end{array}$ & $\begin{array}{l}2412.609 \\
(2038.29)\end{array}$ & $\begin{array}{c}2.353 \\
(10.68)\end{array}$ & $\begin{array}{l}159.019 \\
(106.46)\end{array}$ & $\begin{array}{l}-216.153 \\
(123.43)\end{array}$ & $\begin{array}{l}830.512 \\
(771.80)\end{array}$ & $\begin{array}{l}-191.145 \\
(154.25)\end{array}$ & $\begin{array}{l}68.353 \\
(51.77)\end{array}$ \\
\hline female & $\begin{array}{c}-385.635^{\star \star} \\
(148.34)\end{array}$ & $\begin{array}{c}-467.639 * * * \\
(101.09)\end{array}$ & $\begin{array}{c}7.88 \\
(13.22)\end{array}$ & $\begin{array}{c}108.969 * * * \\
(21.97)\end{array}$ & $\begin{array}{l}-22.511 \\
(13.97)\end{array}$ & $\begin{array}{c}-89.186^{*} \\
(44.00)\end{array}$ & $\begin{array}{l}-4.701 \\
(31.88)\end{array}$ & $\begin{array}{l}44.974 \\
(24.00)\end{array}$ \\
\hline age & $\begin{array}{c}102.926^{\star \star \star} \\
(22.37)\end{array}$ & $\begin{array}{c}59.364^{\star * *} \\
(14.90)\end{array}$ & $\begin{array}{l}0.807 \\
(1.38)\end{array}$ & $\begin{array}{l}1.675 \\
(2.68)\end{array}$ & $\begin{array}{l}1.681 \\
(2.27)\end{array}$ & $\begin{array}{c}51.940 * \star \star \\
(5.53)\end{array}$ & $\begin{array}{l}-0.366 \\
(5.84)\end{array}$ & $\begin{array}{l}-1.565 \\
(2.47)\end{array}$ \\
\hline $\operatorname{age}^{2}$ & $\begin{array}{l}3.680 * \\
(1.65)\end{array}$ & $\begin{array}{l}1.413 \\
(1.03)\end{array}$ & $\begin{array}{l}0.025 \\
(0.08)\end{array}$ & $\begin{array}{l}0.265 \\
(0.27)\end{array}$ & $\begin{array}{l}0.191 \\
(0.17)\end{array}$ & $\begin{array}{l}0.757 \\
(0.42)\end{array}$ & $\begin{array}{l}0.583 \\
(0.43)\end{array}$ & $\begin{array}{c}0.743^{\star \star *} \\
(0.21)\end{array}$ \\
\hline $\operatorname{age}^{3}$ & $\begin{array}{c}-0.136 * \star \\
(0.05)\end{array}$ & $\begin{array}{c}-0.079 * \\
(0.03)\end{array}$ & $\begin{array}{l}0.004 \\
(0.01)\end{array}$ & $\begin{array}{c}0.02 \\
(0.01)\end{array}$ & $\begin{array}{c}-0.011^{*} \\
(0.00)\end{array}$ & $\begin{array}{c}-0.076^{\star \star \star} \\
(0.01)\end{array}$ & $\begin{array}{c}-0.029 * * \\
(0.01)\end{array}$ & $\begin{array}{l}0.026^{\star} \\
(0.01)\end{array}$ \\
\hline Constant & $\begin{array}{c}3440.543^{\star \star \star} \\
(182.23)\end{array}$ & $\begin{array}{c}1844.003^{\star \star \star} \\
(126.81)\end{array}$ & $\begin{array}{c}4.893 \\
(11.48)\end{array}$ & $\begin{array}{l}45.691 \\
(23.51)\end{array}$ & $\begin{array}{c}99.575^{\star \star \star} \\
(13.70)\end{array}$ & $\begin{array}{c}891.255^{\star \star *} \\
(44.54)\end{array}$ & $\begin{array}{c}402.945^{\star \star \star} \\
(41.35)\end{array}$ & $\begin{array}{l}53.628 * \\
(26.63)\end{array}$ \\
\hline
\end{tabular}

Note: Estimates also condition on year effects, results not reported 
Table 4: Correlation Between Cognition Factors and Various Measures of Health Expenditures After Controlling for Observable health

\begin{tabular}{|c|c|c|c|c|c|c|c|c|}
\hline & $\begin{array}{c}\text { Total Medicare } \\
\text { Eligible } \\
\text { Expenditure } \\
\text { b/se }\end{array}$ & $\begin{array}{c}\text { Inpatient } \\
\text { Expenditure } \\
\text { b/se }\end{array}$ & $\begin{array}{c}\text { Hospice Care } \\
\text { Expenditure } \\
\text { b/se }\end{array}$ & $\begin{array}{l}\text { Home Health } \\
\text { Care } \\
\text { Expenditure } \\
\text { b/se }\end{array}$ & $\begin{array}{c}\text { Medical } \\
\text { Equipment } \\
\text { Expenditure } \\
\text { b/se }\end{array}$ & $\begin{array}{c}\text { "Carrier" } \\
\text { Medical } \\
\text { Expenditure } \\
\text { b/se }\end{array}$ & $\begin{array}{c}\text { Oupatient } \\
\text { Medical } \\
\text { Expenditure } \\
\text { b/se }\end{array}$ & $\begin{array}{c}\text { Skilled Nursing } \\
\text { Facility } \\
\text { Expenditure } \\
\text { b/se }\end{array}$ \\
\hline \multirow[t]{2}{*}{ f1 } & -169.852 & -132.894 & -14.902 & $-28.855^{\star}$ & 4.914 & 41.443 & -20.011 & $-40.963^{\star \star}$ \\
\hline & (94.10) & $(74.36)$ & $(9.55)$ & $(12.07)$ & (7.02) & (23.10) & (18.13) & (13.32) \\
\hline \multirow[t]{2}{*}{ f2 } & -37.32 & -18.89 & $-36.195^{\star \star}$ & 0.674 & -2.467 & $62.174^{\star *}$ & -1.781 & $-49.030^{*}$ \\
\hline & $(97.50)$ & (70.66) & (13.51) & (17.13) & (10.73) & (22.99) & (19.09) & (23.26) \\
\hline \multirow[t]{2}{*}{ black } & -350.445 & -279.591 & -20.555 & 37.283 & $50.345^{\star}$ & $-191.068^{\star \star}$ & $187.853^{\star *}$ & $-175.892^{\star \star \star}$ \\
\hline & $(221.80)$ & (153.64) & (18.67) & (37.99) & $(25.09)$ & (61.01) & (68.99) & $(36.37)$ \\
\hline \multirow[t]{2}{*}{ hispanic } & $1172.173^{\star \star}$ & 413.722 & $-61.897^{\star \star \star}$ & $454.570^{\star \star *}$ & $172.147^{\text {** }}$ & $292.944^{*}$ & 197.359 & $-181.121^{\star \star}$ \\
\hline & (409.95) & (251.26) & $(12.37)$ & $(111.41)$ & (56.18) & (118.95) & $(135.89)$ & $(57.79)$ \\
\hline \multirow[t]{2}{*}{ race other } & -479.72 & -268.451 & 2.659 & -48.787 & $-94.968^{\star}$ & -113.061 & 52.271 & -62.742 \\
\hline & (539.11) & (301.84) & $(27.82)$ & $(166.22)$ & $(44.21)$ & (158.19) & (134.95) & (80.21) \\
\hline \multirow[t]{2}{*}{ race non-respor } & 1145.45 & 1686.741 & -1.263 & -110.101 & $-339.690 * *$ & 682.032 & $-359.735^{\star \star}$ & -100.903 \\
\hline & (2222.58) & (1829.66) & (17.89) & $(102.26)$ & $(114.81)$ & (642.31) & $(135.66)$ & $(52.57)$ \\
\hline \multirow[t]{2}{*}{ female } & $-746.734^{\star \star \star}$ & $-642.055^{\star \star \star}$ & 6.937 & $61.041^{*}$ & $-50.224^{\star \star}$ & $-164.279 * \star \star$ & -36.133 & 0.553 \\
\hline & (151.95) & (109.91) & (15.94) & (23.98) & (15.81) & (44.71) & (33.91) & $(24.90)$ \\
\hline \multirow[t]{2}{*}{ age } & $112.999 * * *$ & $63.102^{\star \star \star}$ & 2.621 & $8.158^{* *}$ & 5.840 ** & $44.505^{\star \star \star}$ & -2.909 & $5.629 *$ \\
\hline & $(21.67)$ & $(14.76)$ & (1.51) & (3.16) & $(2.25)$ & (5.32) & (5.59) & (2.87) \\
\hline \multirow[t]{2}{*}{$\operatorname{age}^{2}$} & $-3.063^{\star}$ & $-2.003^{*}$ & -0.104 & -0.439 & -0.243 & $-0.719^{\star}$ & -0.175 & 0.015 \\
\hline & $(1.55)$ & (1.01) & $(0.10)$ & $(0.33)$ & $(0.17)$ & $(0.34)$ & $(0.38)$ & $(0.26)$ \\
\hline \multirow[t]{2}{*}{$\operatorname{age}^{3}$} & -0.027 & -0.023 & 0.004 & 0.023 & -0.004 & $-0.036 * * *$ & -0.012 & $0.026^{*}$ \\
\hline & (0.05) & (0.03) & $(0.01)$ & (0.02) & $(0.00)$ & $(0.01)$ & $(0.01)$ & $(0.01)$ \\
\hline \multirow[t]{2}{*}{ Constant } & $5197.919 * \star \star$ & $2875.639 * \star \star$ & 62.725 & 74.423 & $126.503^{* *}$ & $1490.384^{\star \star \star}$ & $661.569 * \star \star$ & -71.002 \\
\hline & $(440.49)$ & $(308.13)$ & (44.71) & (67.77) & $(38.61)$ & $(136.88)$ & $(101.81)$ & (81.24) \\
\hline
\end{tabular}

Note: Estimates also condition on year effects, results not reported 
Table 5: Robustness Checks: Nonlinear Effects of Cognition

\begin{tabular}{|c|c|c|c|c|c|c|c|c|}
\hline & $\begin{array}{c}\text { Total Medicare } \\
\text { Eligible } \\
\text { Expenditure } \\
\text { b/se }\end{array}$ & $\begin{array}{c}\text { Inpatient } \\
\text { Expenditure } \\
\text { b/se }\end{array}$ & $\begin{array}{c}\text { Hospice Care } \\
\text { Expenditure } \\
\text { b/se }\end{array}$ & $\begin{array}{l}\text { Home Health } \\
\text { Care } \\
\text { Expenditure } \\
\text { b/se }\end{array}$ & $\begin{array}{c}\text { Medical } \\
\text { Equipment } \\
\text { Expenditure } \\
\text { b/se }\end{array}$ & $\begin{array}{c}\text { "Carrier" } \\
\text { Medical } \\
\text { Expenditure } \\
\text { b/se }\end{array}$ & $\begin{array}{c}\text { Oupatient } \\
\text { Medical } \\
\text { Expenditure } \\
\text { b/se }\end{array}$ & $\begin{array}{c}\text { Skilled Nursing } \\
\text { Facility } \\
\text { Expenditure } \\
\text { b/se }\end{array}$ \\
\hline & \multicolumn{8}{|c|}{ Panel A: Allowing for Non-linear Effects of Cognition: No Observable Health Controls } \\
\hline f1 & $\begin{array}{c}-939.981^{\star \star *} \\
(142.90)\end{array}$ & $\begin{array}{c}-510.567^{\star \star \star} \\
(115.15)\end{array}$ & $\begin{array}{c}-28.463^{\star \star} \\
(8.91)\end{array}$ & $\begin{array}{c}-117.375^{\star \star \star} \\
(14.48)\end{array}$ & $\begin{array}{c}-44.655^{\star \star \star} \\
(9.19)\end{array}$ & $\begin{array}{c}-131.725^{\star \star \star} \\
(33.74)\end{array}$ & $\begin{array}{c}-99.763^{\star \star \star} \\
(23.97)\end{array}$ & $\begin{array}{c}-111.863^{\star \star \star} \\
(15.83)\end{array}$ \\
\hline f2 & $\begin{array}{c}-1970.636^{\star \star \star} \\
(410.30)\end{array}$ & $\begin{array}{c}-940.134^{\star \star} \\
(287.40)\end{array}$ & $\begin{array}{c}-78.034 \\
(40.08)\end{array}$ & $\begin{array}{c}-251.648^{\star \star \star} \\
(59.09)\end{array}$ & $\begin{array}{c}-146.196 * \star \star \\
(30.11)\end{array}$ & $\begin{array}{l}-270.837^{*} \\
(123.86)\end{array}$ & $\begin{array}{c}-130.669 \\
(85.12)\end{array}$ & $\begin{array}{c}-353.471^{\star \star \star} \\
(74.96)\end{array}$ \\
\hline Lowest quartile, f1 & $\begin{array}{l}984.216^{\star} \\
(452.38)\end{array}$ & $\begin{array}{l}540.554 \\
(337.84)\end{array}$ & $\begin{array}{l}22.823 \\
(59.07)\end{array}$ & $\begin{array}{c}101.538 \\
(86.07)\end{array}$ & $\begin{array}{c}128.621^{* *} \\
(39.53)\end{array}$ & $\begin{array}{l}243.858 * \\
(114.58)\end{array}$ & $\begin{array}{l}57.529 \\
(87.22)\end{array}$ & $\begin{array}{c}50.123 \\
(101.66)\end{array}$ \\
\hline Lowest quartile, f2 & $\begin{array}{l}380.429 \\
(257.16)\end{array}$ & $\begin{array}{l}309.837 \\
(189.17)\end{array}$ & $\begin{array}{c}2.04 \\
(23.84)\end{array}$ & $\begin{array}{l}22.103 \\
(38.84)\end{array}$ & $\begin{array}{l}14.521 \\
(20.61)\end{array}$ & $\begin{array}{l}46.901 \\
(62.68)\end{array}$ & $\begin{array}{l}12.162 \\
(49.66)\end{array}$ & $\begin{array}{l}32.834 \\
(47.35)\end{array}$ \\
\hline f1 x (Lowest quartile, f1) & $\begin{array}{l}637.713 \\
(421.00)\end{array}$ & $\begin{array}{l}327.618 \\
(310.89)\end{array}$ & $\begin{array}{l}22.627 \\
(58.94)\end{array}$ & $\begin{array}{l}49.241 \\
(75.26)\end{array}$ & $\begin{array}{l}85.235^{\star} \\
(33.23)\end{array}$ & $\begin{array}{l}232.158^{*} \\
(104.07)\end{array}$ & $\begin{array}{l}41.164 \\
(79.25)\end{array}$ & $\begin{array}{c}-33.883 \\
(93.84)\end{array}$ \\
\hline \multirow[t]{2}{*}{ f2 x (Lowest quartile, f2) } & $\begin{array}{c}1836.06^{\star \star *} \\
(439.36)\end{array}$ & $\begin{array}{c}920.596 * * \\
(305.22) \\
\end{array}$ & $\begin{array}{l}37.873 \\
(47.27) \\
\end{array}$ & $\begin{array}{c}211.091^{* *} \\
(66.05)\end{array}$ & $\begin{array}{c}133.691^{\star * *} \\
(33.74)\end{array}$ & $\begin{array}{l}320.723^{*} \\
(129.80)\end{array}$ & $\begin{array}{l}105.84 \\
(89.12) \\
\end{array}$ & $\begin{array}{c}285.643^{\star \star \star} \\
(83.36)\end{array}$ \\
\hline & \multicolumn{8}{|c|}{ Panel B: Allowing for Non-linear Effects of Cognition, Controlling for Observable Health } \\
\hline f1 & $\begin{array}{l}-69.575 \\
(135.67)\end{array}$ & $\begin{array}{l}-55.953 \\
(111.35)\end{array}$ & $\begin{array}{c}-19.269 * \\
(9.25)\end{array}$ & $\begin{array}{l}-27.369 \star \\
(12.89)\end{array}$ & $\begin{array}{l}11.993 \\
(8.73)\end{array}$ & $\begin{array}{l}60.724 \\
(32.77)\end{array}$ & $\begin{array}{l}-2.284 \\
(24.71)\end{array}$ & $\begin{array}{c}-32.531^{\star} \\
(15.58)\end{array}$ \\
\hline f2 & $\begin{array}{c}-460.408 \\
(383.10)\end{array}$ & $\begin{array}{l}-166.598 \\
(277.57)\end{array}$ & $\begin{array}{c}-60.502 \\
(39.78)\end{array}$ & $\begin{array}{c}-57.291 \\
(57.64)\end{array}$ & $\begin{array}{c}-36.111 \\
(28.12)\end{array}$ & $\begin{array}{c}1.918 \\
(118.82)\end{array}$ & $\begin{array}{l}29.059 \\
(81.96)\end{array}$ & $\begin{array}{c}-186.478^{\star} \\
(73.17)\end{array}$ \\
\hline Lowest quartile, f1 & $\begin{array}{l}763.304 \\
(431.09)\end{array}$ & $\begin{array}{l}396.291 \\
(331.38)\end{array}$ & $\begin{array}{l}28.788 \\
(59.33)\end{array}$ & $\begin{array}{c}112.501 \\
(84.41)\end{array}$ & $\begin{array}{c}130.887^{\star \star \star} \\
(34.28)\end{array}$ & $\begin{array}{l}130.369 \\
(111.39)\end{array}$ & $\begin{array}{c}5.319 \\
(84.52)\end{array}$ & $\begin{array}{c}89.388 \\
(100.32)\end{array}$ \\
\hline Lowest quartile, f2 & $\begin{array}{l}220.819 \\
(244.75)\end{array}$ & $\begin{array}{l}229.673 \\
(184.73)\end{array}$ & $\begin{array}{l}-3.522 \\
(23.09)\end{array}$ & $\begin{array}{c}8.843 \\
(37.77)\end{array}$ & $\begin{array}{c}3.518 \\
(19.46)\end{array}$ & $\begin{array}{c}8.022 \\
(60.02)\end{array}$ & $\begin{array}{l}-6.849 \\
(49.07)\end{array}$ & $\begin{array}{l}19.892 \\
(46.10)\end{array}$ \\
\hline f1 x (Lowest quartile, f1) & $\begin{array}{l}330.285 \\
(406.17)\end{array}$ & $\begin{array}{l}122.294 \\
(308.63)\end{array}$ & $\begin{array}{l}30.227 \\
(61.03)\end{array}$ & $\begin{array}{l}80.136 \\
(75.30)\end{array}$ & $\begin{array}{c}85.561^{\star *} \\
(26.56)\end{array}$ & $\begin{array}{c}53.499 \\
(102.21)\end{array}$ & $\begin{array}{c}-32.164 \\
(77.75)\end{array}$ & $\begin{array}{l}34.623 \\
(92.28)\end{array}$ \\
\hline f2 x (Lowest quartile, f2) & $\begin{array}{l}603.638 \\
(410.78) \\
\end{array}$ & $\begin{array}{l}281.772 \\
(295.63) \\
\end{array}$ & $\begin{array}{l}26.241 \\
(46.68) \\
\end{array}$ & $\begin{array}{r}71.093 \\
(63.64) \\
\end{array}$ & $\begin{array}{l}40.044 \\
(31.83) \\
\end{array}$ & $\begin{array}{c}75.959 \\
(124.25) \\
\end{array}$ & $\begin{array}{c}-37.271 \\
(85.58) \\
\end{array}$ & $\begin{array}{c}173.011^{*} \\
(81.39)\end{array}$ \\
\hline
\end{tabular}


Table 6: Fixed Effects Estimates of With-in Person Correlation Between Cognitive Factors and Health

\begin{tabular}{|c|c|c|c|c|}
\hline & $\begin{array}{c}\text { Cognitive } \\
\text { Factor \#1 } \\
\text { b/se }\end{array}$ & $\begin{array}{c}\text { Cognitive } \\
\text { Factor \#2 } \\
\text { b/se }\end{array}$ & $\begin{array}{c}\text { Cognitive } \\
\text { Factor \#1 } \\
\text { b/se }\end{array}$ & $\begin{array}{c}\text { Cognitive } \\
\text { Factor \#2 } \\
\text { b/se }\end{array}$ \\
\hline \multirow[t]{2}{*}{ \# of diagnoses } & $-0.105^{\star \star \star}$ & $-0.049^{\star \star \star}$ & & \\
\hline & $(0.0058)$ & $(0.0063)$ & & \\
\hline \multirow[t]{2}{*}{ \# of (I)ADLS with difficulty } & $-0.034^{* * *}$ & $-0.051^{\star \star \star}$ & & \\
\hline & $(0.0025)$ & 0.0037 & & \\
\hline \multicolumn{5}{|l|}{ Self Reported Health } \\
\hline \multirow[t]{2}{*}{ Excellent } & & & $0.276^{\star \star \star}$ & $0.126^{\star \star \star}$ \\
\hline & & & $(0.0267)$ & (0.0296) \\
\hline \multirow[t]{2}{*}{ Very Good } & & & $0.213^{\star \star \star}$ & $0.105^{\star \star \star}$ \\
\hline & & & $(0.0218)$ & $(0.0257)$ \\
\hline \multirow[t]{2}{*}{ Good } & & & $0155^{\star \star \star}$ & $0.085^{\star \star \star}$ \\
\hline & & & $(0.0201)$ & $(0.0245)$ \\
\hline \multirow[t]{2}{*}{ Fair } & & & $0.104^{\star \star \star}$ & $0.050^{\star \star}$ \\
\hline & & & $(0.0186)$ & (0.0229) \\
\hline \multirow[t]{2}{*}{ Non-response } & & & -0.280 & -0.0566 \\
\hline & & & $(0.2033)$ & $(0.1304)$ \\
\hline \multirow[t]{2}{*}{ Constant } & $0.344^{\star * *}$ & $0.247^{\star \star \star}$ & $-0.158^{\star \star \star}$ & $-0.084^{\star \star \star}$ \\
\hline & $(0.01)$ & $(0.02)$ & $(0.02)$ & $(0.02)$ \\
\hline
\end{tabular}


Table 7: Is it End-of-Life Effect?

\begin{tabular}{|c|c|c|c|c|c|c|c|c|}
\hline & $\begin{array}{c}\text { Total Medicare } \\
\text { Eligible } \\
\text { Expenditure } \\
\text { b/se }\end{array}$ & $\begin{array}{c}\text { Inpatient } \\
\text { Expenditure } \\
\text { b/se }\end{array}$ & $\begin{array}{c}\text { Hospice Care } \\
\text { Expenditure } \\
\text { b/se }\end{array}$ & $\begin{array}{c}\text { Home Health } \\
\text { Care } \\
\text { Expenditure } \\
\text { b/se } \\
\end{array}$ & $\begin{array}{c}\text { Medical } \\
\text { Equipment } \\
\text { Expenditure } \\
\text { b/se } \\
\end{array}$ & $\begin{array}{c}\text { "Carrier" } \\
\text { Medical } \\
\text { Expenditure } \\
\text { b/se } \\
\end{array}$ & $\begin{array}{c}\text { Oupatient } \\
\text { Medical } \\
\text { Expenditure } \\
\text { b/se } \\
\end{array}$ & $\begin{array}{c}\text { Skilled Nursing } \\
\text { Facility } \\
\text { Expenditure } \\
\text { b/se }\end{array}$ \\
\hline & \multicolumn{8}{|c|}{ Panel A: Allowing For Non-linear Effects of Cognition and End of Life Dummy: No Observable Health Controls } \\
\hline f1 & $\begin{array}{c}-746.396 * \star \star \\
(140.43)\end{array}$ & $\begin{array}{c}-399.284^{\star \star \star} \\
(114.73)\end{array}$ & $\begin{array}{c}-19.956^{\star} \\
(8.25)\end{array}$ & $\begin{array}{c}-107.571^{\star \star \star} \\
(14.38)\end{array}$ & $\begin{array}{c}-37.038^{\star \star \star} \\
(9.13)\end{array}$ & $\begin{array}{c}-90.254^{\star \star} \\
(33.21)\end{array}$ & $\begin{array}{c}-80.911^{\star \star \star} \\
(23.74)\end{array}$ & $\begin{array}{c}-94.632^{\star \star \star} \\
(15.63)\end{array}$ \\
\hline $\mathrm{f} 2$ & $\begin{array}{c}-1544.460 * \star \star \\
(398.44)\end{array}$ & $\begin{array}{c}-695.146^{\star} \\
(282.78)\end{array}$ & $\begin{array}{c}-59.304 \\
(39.12)\end{array}$ & $\begin{array}{c}-230.064^{\star \star \star} \\
(58.77)\end{array}$ & $\begin{array}{c}-129.427^{\star \star \star} \\
(29.85)\end{array}$ & $\begin{array}{l}-179.54 \\
(123.02)\end{array}$ & $\begin{array}{l}-89.167 \\
(84.84)\end{array}$ & $\begin{array}{c}-315.536 * \star \star \\
(73.69)\end{array}$ \\
\hline Lowest quartile, f1 & $\begin{array}{c}1078.027^{*} \\
(437.63)\end{array}$ & $\begin{array}{l}594.481 \\
(329.88)\end{array}$ & $\begin{array}{l}26.946 \\
(59.07)\end{array}$ & $\begin{array}{l}106.289 \\
(85.81)\end{array}$ & $\begin{array}{c}132.312^{\star \star \star} \\
(39.27)\end{array}$ & $\begin{array}{l}263.954^{*} \\
(113.04)\end{array}$ & $\begin{array}{l}66.665 \\
(86.88)\end{array}$ & $\begin{array}{c}58.473 \\
(100.92)\end{array}$ \\
\hline Lowest quartile, f2 & $\begin{array}{l}272.888 \\
(248.16)\end{array}$ & $\begin{array}{l}248.017 \\
(184.52)\end{array}$ & $\begin{array}{l}-2.687 \\
(23.75)\end{array}$ & $\begin{array}{l}16.656 \\
(38.69)\end{array}$ & $\begin{array}{l}10.289 \\
(20.38)\end{array}$ & $\begin{array}{l}23.863 \\
(61.44)\end{array}$ & $\begin{array}{c}1.689 \\
(49.17)\end{array}$ & $\begin{array}{l}23.261 \\
(46.98)\end{array}$ \\
\hline $\mathrm{f} 1 \mathrm{x}$ (Lowest quartile, f1) & $\begin{array}{l}963.126 * \\
(407.27)\end{array}$ & $\begin{array}{l}514.682 \\
(301.46)\end{array}$ & $\begin{array}{l}36.929 \\
(59.39)\end{array}$ & $\begin{array}{l}65.721 \\
(75.02)\end{array}$ & $\begin{array}{c}98.039 * * \\
(33.07)\end{array}$ & $\begin{array}{c}301.869 * \star \\
(103.39)\end{array}$ & $\begin{array}{l}72.853 \\
(79.64)\end{array}$ & $\begin{array}{l}-4.918 \\
(93.11)\end{array}$ \\
\hline f2 x (Lowest quartile, f2) & $\begin{array}{c}1558.982^{\star \star \star} \\
(426.45)\end{array}$ & $\begin{array}{l}761.320 * \\
(299.58)\end{array}$ & $\begin{array}{l}25.70 \\
(46.76)\end{array}$ & $\begin{array}{c}197.059 * * \\
(65.73)\end{array}$ & $\begin{array}{c}122.789 * \star \star \\
(33.42)\end{array}$ & $\begin{array}{l}261.367^{*} \\
(128.69)\end{array}$ & $\begin{array}{l}78.86 \\
(88.62)\end{array}$ & $\begin{array}{c}260.980^{\star *} \\
(82.27)\end{array}$ \\
\hline \multirow[t]{2}{*}{ End of life } & $\begin{array}{c}9502.023^{\star \star \star} \\
(421.00)\end{array}$ & $\begin{array}{c}5462.246 * \star \star \\
(319.75)\end{array}$ & $\begin{array}{c}417.5966^{\star \star \star} \\
(59.10)\end{array}$ & $\begin{array}{c}481.231^{\star \star *} \\
(55.51)\end{array}$ & $\begin{array}{c}373.875^{\star \star \star} \\
(31.89)\end{array}$ & $\begin{array}{c}2035.550 * * \star \\
(120.85)\end{array}$ & $\begin{array}{c}925.319 * * \star \\
(91.95)\end{array}$ & $\begin{array}{c}845.792^{\star \star \star} \\
(77.18)\end{array}$ \\
\hline & \multicolumn{8}{|c|}{ Panel B: Allowing for Non-linear Effects of Cognition and End of Life Dummy, Controlling for Observable Health } \\
\hline f1 & $\begin{array}{c}4.811 \\
(133.97)\end{array}$ & $\begin{array}{l}-11.256 \\
(110.87)\end{array}$ & $\begin{array}{c}-15.44 \\
(9.00)\end{array}$ & $\begin{array}{l}-25.09 \\
(12.85)\end{array}$ & $\begin{array}{c}13.879 \\
(8.71)\end{array}$ & $\begin{array}{l}76.477^{\star} \\
(32.46)\end{array}$ & $\begin{array}{c}4.673 \\
(24.62)\end{array}$ & $\begin{array}{c}-25.768 \\
(15.48)\end{array}$ \\
\hline f2 & $\begin{array}{l}-271.389 \\
(377.12)\end{array}$ & $\begin{array}{l}-53.021 \\
(275.08)\end{array}$ & $\begin{array}{l}-50.772 \\
(39.40)\end{array}$ & $\begin{array}{c}-51.5 \\
(57.46)\end{array}$ & $\begin{array}{c}-31.318 \\
(28.04)\end{array}$ & $\begin{array}{c}41.947 \\
(118.57)\end{array}$ & $\begin{array}{l}46.736 \\
(81.86)\end{array}$ & $\begin{array}{c}-169.292^{*} \\
(72.48)\end{array}$ \\
\hline Lowest quartile, f1 & $\begin{array}{l}803.825 \\
(423.71)\end{array}$ & $\begin{array}{c}420.64 \\
(326.65)\end{array}$ & $\begin{array}{l}30.874 \\
(59.38)\end{array}$ & $\begin{array}{c}113.742 \\
(84.38)\end{array}$ & $\begin{array}{c}131.914^{\star \star *} \\
(34.26)\end{array}$ & $\begin{array}{c}138.95 \\
(110.53)\end{array}$ & $\begin{array}{c}9.109 \\
(84.40)\end{array}$ & $\begin{array}{l}93.072 \\
(99.95)\end{array}$ \\
\hline Lowest quartile, f2 & $\begin{array}{c}153.46 \\
(238.79)\end{array}$ & $\begin{array}{l}189.199 \\
(181.37)\end{array}$ & $\begin{array}{l}-6.989 \\
(23.04)\end{array}$ & $\begin{array}{c}6.779 \\
(37.78)\end{array}$ & $\begin{array}{c}1.81 \\
(19.34)\end{array}$ & $\begin{array}{l}-6.243 \\
(59.24)\end{array}$ & $\begin{array}{c}-13.149 \\
(48.78)\end{array}$ & $\begin{array}{l}13.768 \\
(45.88)\end{array}$ \\
\hline $\mathrm{f} 1 \times$ (Lowest quartile, $\mathrm{f} 1)$ & $\begin{array}{l}553.113 \\
(398.64)\end{array}$ & $\begin{array}{l}256.186 \\
(302.09)\end{array}$ & $\begin{array}{l}41.697 \\
(61.58)\end{array}$ & $\begin{array}{l}86.962 \\
(75.09)\end{array}$ & $\begin{array}{c}91.211^{\star * *} \\
(26.64)\end{array}$ & $\begin{array}{l}100.688 \\
(101.96)\end{array}$ & $\begin{array}{c}-11.325 \\
(78.11)\end{array}$ & $\begin{array}{l}54.883 \\
(91.88)\end{array}$ \\
\hline f2 x (Lowest quartile, f2) & $\begin{array}{c}495.94 \\
(404.13)\end{array}$ & $\begin{array}{l}217.059 \\
(292.51)\end{array}$ & $\begin{array}{l}20.697 \\
(46.48)\end{array}$ & $\begin{array}{l}67.794 \\
(63.51)\end{array}$ & $\begin{array}{l}37.313 \\
(31.73)\end{array}$ & $\begin{array}{c}53.151 \\
(123.82)\end{array}$ & $\begin{array}{c}-47.343 \\
(85.34)\end{array}$ & $\begin{array}{c}163.219 * \\
(80.81)\end{array}$ \\
\hline End of life & $\begin{array}{c}7072.461^{\star \star \star} \\
(413.51)\end{array}$ & $\begin{array}{c}4249.683^{\star \star \star} \\
(322.74)\end{array}$ & $\begin{array}{c}364.052^{\star \star \star} \\
(52.64)\end{array}$ & $\begin{array}{c}216.661^{\star \star \star} \\
(57.81)\end{array}$ & $\begin{array}{c}179.340^{\star \star *} \\
(29.89)\end{array}$ & $\begin{array}{c}1497.767^{\star \star \star} \\
(112.78)\end{array}$ & $\begin{array}{c}661.448^{\star * *} \\
(87.37)\end{array}$ & $\begin{array}{c}643.041^{\star \star \star} \\
(76.66)\end{array}$ \\
\hline
\end{tabular}


Table 8: Fixed Effect Regressions

\begin{tabular}{|c|c|c|c|c|c|c|c|c|}
\hline & $\begin{array}{c}\text { Total Medicare } \\
\text { Eligible } \\
\text { Expenditure } \\
\text { b/se }\end{array}$ & $\begin{array}{c}\text { Inpatient } \\
\text { Expenditure } \\
\text { b/se }\end{array}$ & $\begin{array}{c}\text { Hospice Care } \\
\text { Expenditure } \\
\text { b/se }\end{array}$ & $\begin{array}{c}\text { Home Health } \\
\text { Care } \\
\text { Expenditure } \\
\text { b/se }\end{array}$ & $\begin{array}{c}\text { Medical } \\
\text { Equipment } \\
\text { Expenditure } \\
\text { b/se }\end{array}$ & $\begin{array}{c}\text { "Carrier" } \\
\text { Medical } \\
\text { Expenditure } \\
\text { b/se }\end{array}$ & $\begin{array}{c}\text { Oupatient } \\
\text { Medical } \\
\text { Expenditure } \\
\text { b/se }\end{array}$ & $\begin{array}{c}\text { Skilled Nursing } \\
\text { Facility } \\
\text { Expenditure } \\
\text { b/se }\end{array}$ \\
\hline & \multicolumn{8}{|c|}{ Panel A: No Observable Health Controls } \\
\hline f1 & $\begin{array}{c}-752.323^{\star \star \star} \\
(146.86)\end{array}$ & $\begin{array}{c}-460.407^{\star \star \star} \\
(113.93)\end{array}$ & $\begin{array}{c}-44.667^{\star \star} \\
(14.12)\end{array}$ & $\begin{array}{c}-60.659 * \\
(23.84)\end{array}$ & $\begin{array}{c}4.297 \\
(10.36)\end{array}$ & $\begin{array}{c}-95.306^{\star} \\
(42.06)\end{array}$ & $\begin{array}{c}-81.883^{\star \star} \\
(29.74)\end{array}$ & $\begin{array}{c}-119.928^{\star \star \star} \\
(27.82)\end{array}$ \\
\hline f2 & $\begin{array}{c}-1432.303^{\star \star \star} \\
(433.27)\end{array}$ & $\begin{array}{c}-655.520^{\star} \\
(321.65)\end{array}$ & $\begin{array}{c}-157.769 * \star \\
(54.86)\end{array}$ & $\begin{array}{c}-123.59 \\
(64.72)\end{array}$ & $\begin{array}{l}-49.097 \\
(28.31)\end{array}$ & $\begin{array}{c}-209.785 \\
(126.72)\end{array}$ & $\begin{array}{c}-103.382 \\
(88.10)\end{array}$ & $\begin{array}{c}-346.187^{\star \star \star} \\
(101.71)\end{array}$ \\
\hline Lowest quartile, f1 & $\begin{array}{c}43.668 \\
(476.87)\end{array}$ & $\begin{array}{c}93.441 \\
(384.21)\end{array}$ & $\begin{array}{l}-7.504 \\
(50.52)\end{array}$ & $\begin{array}{l}63.735 \\
(85.30)\end{array}$ & $\begin{array}{l}23.798 \\
(28.94)\end{array}$ & $\begin{array}{l}103.928 \\
(119.36)\end{array}$ & $\begin{array}{l}-27.626 \\
(90.18)\end{array}$ & $\begin{array}{l}-213.934 \\
(128.50)\end{array}$ \\
\hline Lowest quartile, f2 & $\begin{array}{l}197.531 \\
(256.51)\end{array}$ & $\begin{array}{l}154.197 \\
(195.40)\end{array}$ & $\begin{array}{l}12.444 \\
(29.34)\end{array}$ & $\begin{array}{l}47.133 \\
(38.81)\end{array}$ & $\begin{array}{l}-7.242 \\
(17.05)\end{array}$ & $\begin{array}{l}-3.221 \\
(63.94)\end{array}$ & $\begin{array}{l}31.909 \\
(53.89)\end{array}$ & $\begin{array}{l}33.857 \\
(56.85)\end{array}$ \\
\hline f1 x (Lowest quartile, f1) & $\begin{array}{c}8.306 \\
(457.12)\end{array}$ & $\begin{array}{c}35.235 \\
(359.03)\end{array}$ & $\begin{array}{c}8.425 \\
(54.95)\end{array}$ & $\begin{array}{l}44.073 \\
(85.32)\end{array}$ & $\begin{array}{l}-12.645 \\
(27.78)\end{array}$ & $\begin{array}{l}113.349 \\
(108.60)\end{array}$ & $\begin{array}{c}-35.873 \\
(86.59)\end{array}$ & $\begin{array}{l}-223.511 \\
(128.37)\end{array}$ \\
\hline \multirow[t]{2}{*}{ f2 x (Lowest quartile, f2) } & $\begin{array}{c}1221.155^{\star \star} \\
(460.76)\end{array}$ & $\begin{array}{l}599.983 \\
(343.07) \\
\end{array}$ & $\begin{array}{c}112.776 \\
(60.76) \\
\end{array}$ & $\begin{array}{r}89.86 \\
(71.29) \\
\end{array}$ & $\begin{array}{l}35.751 \\
(29.30) \\
\end{array}$ & $\begin{array}{l}200.405 \\
(131.55) \\
\end{array}$ & $\begin{array}{c}104.351 \\
(88.42) \\
\end{array}$ & $\begin{array}{l}259.272^{\star} \\
(113.64) \\
\end{array}$ \\
\hline & \multicolumn{8}{|c|}{ Panel B: Controlling for Observable Health } \\
\hline $\mathrm{f} 1$ & $\begin{array}{c}-521.170^{\star \star \star} \\
(139.61)\end{array}$ & $\begin{array}{c}-327.684^{\star \star} \\
(109.63)\end{array}$ & $\begin{array}{c}-35.909 * \star \\
(13.81)\end{array}$ & $\begin{array}{c}-43.228 \\
(22.48)\end{array}$ & $\begin{array}{c}9.585 \\
(10.25)\end{array}$ & $\begin{array}{l}-42.021 \\
(41.05)\end{array}$ & $\begin{array}{c}-56.346 \\
(29.21)\end{array}$ & $\begin{array}{c}-93.065^{\star \star \star} \\
(27.06)\end{array}$ \\
\hline f2 & $\begin{array}{c}-915.452^{*} \\
(423.41)\end{array}$ & $\begin{array}{l}-382.755 \\
(319.23)\end{array}$ & $\begin{array}{c}-132.926^{*} \\
(52.51)\end{array}$ & $\begin{array}{c}-67.008 \\
(61.55)\end{array}$ & $\begin{array}{l}-27.694 \\
(27.94)\end{array}$ & $\begin{array}{l}-112.562 \\
(124.47)\end{array}$ & $\begin{array}{c}-41.408 \\
(88.49)\end{array}$ & $\begin{array}{c}-266.770 \text { ** } \\
(99.35)\end{array}$ \\
\hline Lowest quartile, f1 & $\begin{array}{c}13.119 \\
(469.62)\end{array}$ & $\begin{array}{c}96.465 \\
(382.09)\end{array}$ & $\begin{array}{l}-3.165 \\
(49.55)\end{array}$ & $\begin{array}{l}70.109 \\
(85.49)\end{array}$ & $\begin{array}{l}41.111 \\
(27.09)\end{array}$ & $\begin{array}{c}49.75 \\
(115.96)\end{array}$ & $\begin{array}{l}-35.002 \\
(88.61)\end{array}$ & $\begin{array}{l}-184.122 \\
(129.05)\end{array}$ \\
\hline Lowest quartile, f2 & $\begin{array}{l}213.755 \\
(248.29)\end{array}$ & $\begin{array}{l}157.165 \\
(191.82)\end{array}$ & $\begin{array}{c}9.613 \\
(26.98)\end{array}$ & $\begin{array}{l}49.812 \\
(38.69)\end{array}$ & $\begin{array}{l}-3.472 \\
(16.67)\end{array}$ & $\begin{array}{c}2.601 \\
(62.20)\end{array}$ & $\begin{array}{l}34.564 \\
(53.02)\end{array}$ & $\begin{array}{l}43.471 \\
(55.83)\end{array}$ \\
\hline $\mathrm{f} 1 \times$ (Lowest quartile, f1) & $\begin{array}{c}45.266 \\
(451.87)\end{array}$ & $\begin{array}{c}52.823 \\
(360.19)\end{array}$ & $\begin{array}{l}21.374 \\
(54.21)\end{array}$ & $\begin{array}{l}72.001 \\
(85.22)\end{array}$ & $\begin{array}{l}14.138 \\
(25.80)\end{array}$ & $\begin{array}{c}53.328 \\
(106.34)\end{array}$ & $\begin{array}{l}-37.882 \\
(84.34)\end{array}$ & $\begin{array}{l}-163.195 \\
(128.44)\end{array}$ \\
\hline f2 x (Lowest quartile, f2) & $\begin{array}{l}822.769 \\
(450.26) \\
\end{array}$ & $\begin{array}{l}378.022 \\
(340.06) \\
\end{array}$ & $\begin{array}{r}92.753 \\
(58.00) \\
\end{array}$ & $\begin{array}{r}59.494 \\
(68.92) \\
\end{array}$ & $\begin{array}{l}24.163 \\
(29.03) \\
\end{array}$ & $\begin{array}{l}109.471 \\
(128.38) \\
\end{array}$ & $\begin{array}{l}48.793 \\
(88.55) \\
\end{array}$ & $\begin{array}{l}223.743^{*} \\
(112.71) \\
\end{array}$ \\
\hline
\end{tabular}


Table 9: Cognition Factors and Admissions

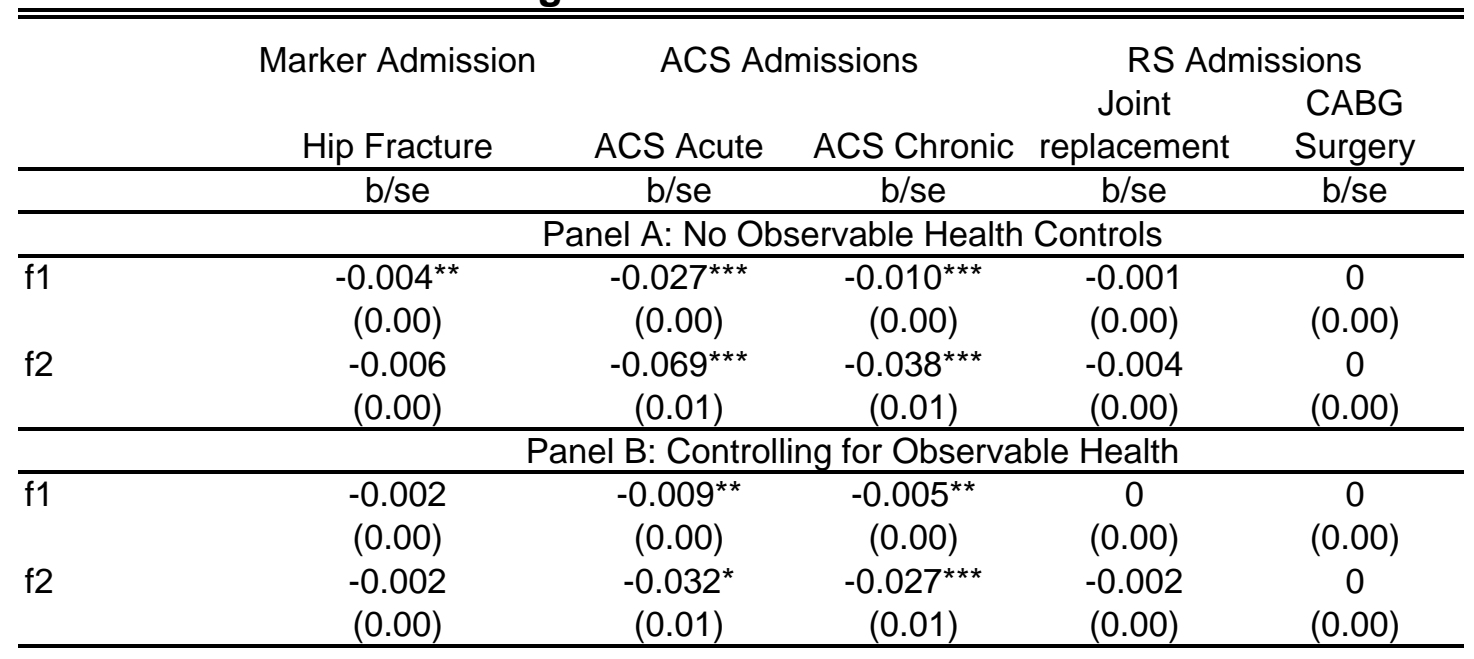

